\title{
Spontaneous Mediumship Experiences Among Near-Death Experiencers: A Qualitative Study
}

\author{
Ryan D. Foster, PhD, Bethany M. Kahoe, BA, \\ and Danijela H. Nardelli, BS \\ Marymount University
}

\begin{abstract}
We describe results of a qualitative study investigating spontaneous mediumship experiences (SMEs) of near-death experiencers (NDErs). Using archival data from a prior survey (Holden, Foster, \& Kinsey, 2014), we used cross-comparison qualitative analysis to examine emerged themes of participants' descriptions of SME characteristics, challenges of SMEs, and strategies to cope with SMEs. We identified 19 themes across 3 research questions. We discuss implications, including our urge to NDE researchers to continue investigating SMEs among NDErs to provide deeper clarity and understanding of this NDE aftereffect.
\end{abstract}

KEY WORDS: near-death experiences, aftereffects, spontaneous mediumship experiences, after-death communication, mediumship

Near-death experiencers (NDErs) report a variety of aftereffects that near-death experience (NDE) researchers continue to make efforts to understand fully. Noyes, Fenwick, Holden, and Christian (2009) summarized 30 years of investigations into NDE aftereffects and categorized post-NDE changes and alterations into five major themes: perception of self, relationship to others, attitude toward life, paranormal phenomena, and perception and consciousness. Examples of typical NDE

\footnotetext{
Ryan D. Foster, PhD, LPC-S, NCC, CHST, was assistant professor in the Department of Counseling at Marymount University in Arlington, VA, at the time of preparation of this article. He is now assistant professor and clinic coordinator in the Department of Counseling at Tarleton State University, Waco, TX. Bethany M. Kahoe, BA, and Danijela H. Nardelli, BS, were clinical mental health counseling master's students in the Department of Counseling at Marymount University; they contributed equally to authorship of this manuscript. Correspondence regarding this article should be sent to Dr. Foster at email: rdfoster@tarleton.edu.
} 
aftereffects include reduced death anxiety, new sense of meaning, outof-body experiences, physiological changes, and transformed religious and/or spiritual beliefs. Although the NDE literature is replete with reports of aftereffects, it was not until Holden, Foster, and Kinsey's (2014) quantitative study that researchers identified what is known as a spontaneous mediumship experience (SME), a type of paranormal aftereffect.

Holden et al. (2014) defined SMEs as a subtype of after-death communication (ADC) in which, in the context of NDE aftereffects, an NDEr experiences "an uninvited visit by a deceased person who asked the NDEr to convey a message to another living person" (p. 67). For a comprehensive yet concise review of research on ADC, we refer readers to Holden (2017). Mediumship is related to ADC; however, in mediumship, "a third person acts as a medium of communication between the discarnate and the living person" (Holden et al., 2014, p. 70). As in ADC more generally, mediumship experiences may be intentional or spontaneous, with a majority of non-NDEr mediumship experiences described as intentional (e.g., Guggenheim \& Guggenheim, 1995; Knight, 2011; LaGrand, 1997; Ring, 2008; Streit-Horn, 2011). Furthermore, the communication in mediumship experiences is meant for a person other than the recipient medium, whereas in ADC the communication is meant for the ADC experiencer (ADCr). Finally, traditional mediums tend to know the person to whom the message is directed, whereas SMErs may have no familiarity with the third party. Holden et al. (2014) provided a detailed description of context, features, and circumstances surrounding SMEs.

Holden et al. (2014) conducted a survey in which 89 participants who self-identified as NDErs and who met Greyson's (1983) NDE Scale criterion of a score of 7 or higher responded to a series of questions regarding experiences of spontaneous mediumship. In Holden et al.'s (2014) exploratory mixed-methods study, they found that a large number $(41.9 \%)$ of participants reported having experienced at least one SME after their first or only NDE. Most (47.0\%) participants reported little to no distress related to their SMEs, but $25 \%$ reported moderate to extreme distress. In terms of coping with SMEs, a majority (45.0\%) of participants indicated that they did not seek assistance to cope with their SMEs, whereas a little over a quarter (28.0\%) of participants had sought help. Holden et al. (2014) called for further research on SMEs as an aftereffect of NDEs and specified that qualitative research would help add to the scientific knowledge base.

Responding to Holden et al.'s (2014) call for qualitative evidence 
of SMEs among NDErs, Foster, Lee, and Duvall (2015) followed up with two case studies in which NDErs reported detailed anecdotal SMEs. In this article we follow those authors' convention to refer to the perceived spirit or consciousness of a physically deceased person as a discarnate.

The first case study participant was Alexandria, a 51-year-old White female who had had three NDEs. She stated that after her first childhood NDE, her SMEs took place on a regular basis. After her second childhood NDE, her SMEs decreased in frequency. Her third NDE, during a car accident in her young adulthood, appeared to activate increased frequency of SMEs, and she noted that since then "her SMEs have been too numerous to count" (p. 47). Alexandria reported that SMEs could be challenging primarily because of others' judgmental reactions to her and fear that others would presume that she is insane. However, she also reported that she has witnessed positive outcomes as a result of communicating messages received from discarnates to third parties. Moreover, she stated that she coped positively with SMEs by reading NDE and mediumship literature and conversing with experts. She also identified attending International Association for Near-Death Studies (IANDS) conferences as a helpful coping strategy.

The second case study participant was Beth, a 50-year-old White female who had an NDE during a medical procedure when she was 43 years old (Foster et al., 2015). At the time of her interview, she estimated that she had experienced 100 or more SMEs since her NDE. Beth reported that SMEs could be incredibly distressing at times, because many of the discarnates who contact her were self-identified perpetrators or victims of violent crimes. She stated that she found a way to reduce distressing aspects of her SMEs through journaling and setting boundaries with discarnates, such as when and how to contact her. Like Alexandria, Beth reported that communicating messages to living people can be distressing based on others' reactions. Beth stated that, on the other hand, the most helpful way of coping with SMEs has been veridical experiences: times when, upon delivering a message from a discarnate to a living person, the person validated the accuracy of the message content.

It seems clear that the evidence base for SMEs as a likely aftereffect of NDEs is increasing. Because this area of investigation is in its infancy, Holden et al. (2014) gathered qualitative and quantitative data in their original survey. During that study, the first author of the current study, Foster, archived the qualitative data for future analysis. 
According to Creswell (2012), qualitative data can provide researchers with a richer understanding of the lived experiences of participants. Qualitative studies can reveal intricacies of research participants' responses in ways that quantitative studies might not. When investigators view phenomena through multiple, complementary lenses-in this case, quantitative, case study, and now qualitative-researchers can develop a broader and deeper understanding of the questions they are seeking to explore. Therefore, our aim in the current study was to analyze the archived qualitative data gathered during the Holden et al. (2014) survey in order to develop a more nuanced comprehension of SMEs as reported by NDErs. Specifically, we explored participants' narratives with a focus on three major questions: What are characteristics of SMEs? What is distressing or challenging about SMEs? What is helpful in coping with SMEs? Following is a description of the method by which we examined these questions as well as a report of our results and a discussion of their implications.

\section{Methodology}

\section{Participants and Data Collection}

In the original Holden et al. (2014) study, 89 adult participants recruited primarily through IANDS's 45 U.S. local groups responded to an author-created 38-item online survey administered via Qualtrics survey software. The items included several open-ended narrative questions in which the researchers asked participants to describe their SMEs in detail, including circumstances, contents, and aftermath; to discuss challenging or distressing aspects of SMEs; and to describe strategies they found helpful in coping with their SMEs. Foster archived these qualitative data for later analysis.

Upon obtaining Institutional Review Board (IRB) approval to analyze archival data, two of us, Nardelli and Kahoe, who were trained in cross-comparison qualitative data analysis, independently analyzed the narrative data for emerging themes. First, we independently read through the entire set of 89 survey responses and reached consensus to eliminate from further analysis 48 responses that either lacked open-ended narratives altogether or contained narratives that did not discuss clearly the subject matter of SMEs. We continued our analysis with narratives provided by the remaining 41 participants, whose demographics are summarized in Table 1. 
Table 1 Participant Demographics $(\mathrm{N}=41)$

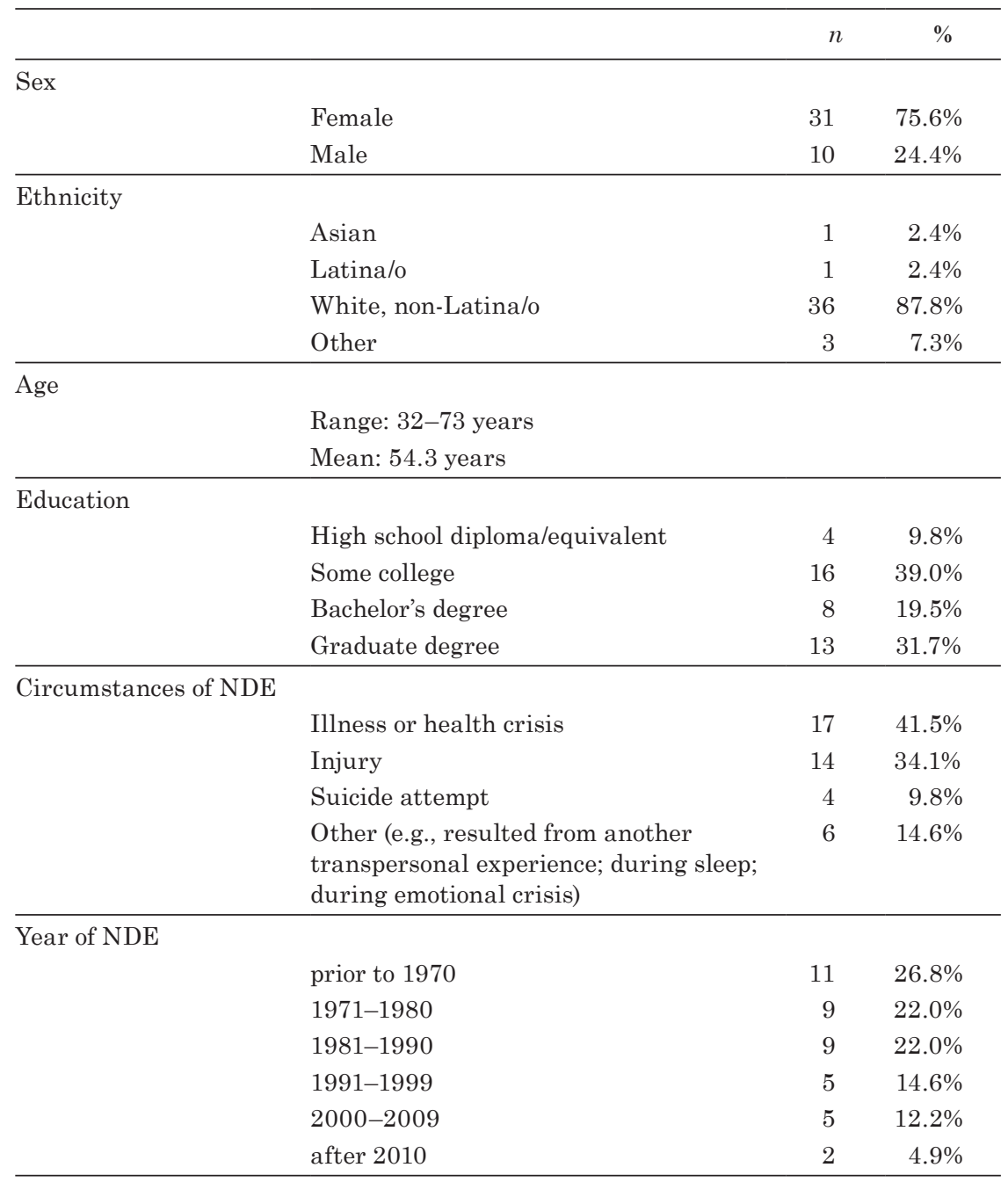

\section{Qualitative Analysis}

In the first phase of the analysis, using Microsoft Excel software and a variation of a cutting and sorting technique for theme identification that Ryan and Bernard (2003) had outlined, we independently coded the narratives by identifying, labeling, and sorting them into 
an initial set of themes. Whereas Nardelli tended to identify narrower themes by maximizing the differences between the narratives, Kahoe tended to identify broader themes by minimizing the narrative differences. This approach enabled us to begin with a large set of themes that could then be refined during the later phases of analysis (Ryan \& Bernard, 2003).

In the second phase of analysis, we reconciled the two sets of independently identified themes by comparing the initial themes and observing differences, similarities, and the degree to which the independently observed themes overlapped and, thus, could be merged into broader themes (Ryan \& Bernard, 2003). Furthermore, we compared relevant quoted passages from these narratives as well as our perceptions of the rationale and meaning behind the identified themes. Subsequently, we agreed on a revised set of themes for each of the three research questions. As a way of determining a theme and its relevance, we calculated the frequency of the theme occurrence across the 41 open-ended narrative responses and clarity of the selected quotes. Ultimately, we followed Creswell's (2012) guideline that one participant's response may indicate a theme; therefore, clarity was valued over frequency when we coded a theme. Using this agreed-upon set of themes, we independently coded the narratives again.

During the third and final phase of the analysis, we used the themes from the final coding in phase two to compare and contrast themes, to quote text sections that pertained to the themes, and to specify our rationale for choosing the themes (Ryan \& Bernard, 2003). Lastly, we decided whether each identified theme was present and relevant in each of the narratives with respect to the three research questions and which quoted text selections best represented each theme.

\section{Results}

After we completed analysis and organized these data, we identified 19 themes: 7 that seemed to us to relate most closely to research question 1, "What are the characteristics of SMEs?"; 7 related to research question 2, "What is distressing or challenging about SMEs?"; and 5 related to research question 3, "What is helpful in coping with SMEs?" Results appear in Tables 2, 3, and 4, respectively. In each table, themes appear in order from most to least frequently matched to participant narratives. For each theme, we present the name we gave the theme (Theme), the criterion we used in matching the theme to participant narratives (Criterion), the number and percentage of 
Table 2 Themes Related to Research Question 1: Characteristics of SMEs $(\mathrm{N}=41)$

\begin{tabular}{|c|c|c|c|c|}
\hline Theme & Criterion & $n$ & $\%$ & Sample Statement \\
\hline Family & $\begin{array}{l}\text { Referenced family mem- } \\
\text { bers in a meaningful way } \\
\text { or SMEs with deceased } \\
\text { family members }\end{array}$ & 24 & $58.5 \%$ & $\begin{array}{l}\text { "After my father died he } \\
\text { came to me one night and } \\
\text { sat on the edge of my bed." }\end{array}$ \\
\hline $\begin{array}{l}\text { Compelled to } \\
\text { act/help }\end{array}$ & $\begin{array}{l}\text { Described an SME in } \\
\text { which the individual was } \\
\text { moved to action or assis- } \\
\text { tance in some way }\end{array}$ & 8 & $19.5 \%$ & $\begin{array}{l}\text { "I felt compelled to re- } \\
\text { spond with kindness and } \\
\text { compassion, according to } \\
\text { the directive of Mr. X." }\end{array}$ \\
\hline $\begin{array}{l}\text { Comfort and } \\
\text { reassurance }\end{array}$ & $\begin{array}{l}\text { Discussed a message from } \\
\text { a discarnate of comfort and } \\
\text { reassurance, either to the } \\
\text { individual directly or to } \\
\text { loved ones }\end{array}$ & 7 & $17.1 \%$ & $\begin{array}{l}\text { "At his funeral, he came to } \\
\text { me and said kind, healing } \\
\text { messages to me." }\end{array}$ \\
\hline Forgiveness & $\begin{array}{l}\text { Discussed forgiving one- } \\
\text { self, a loved one, or another } \\
\text { individual }\end{array}$ & 4 & $9.8 \%$ & $\begin{array}{l}\text { "I took this to mean that } \\
\text { he wanted me to forgive } \\
\text { the other teachers and to } \\
\text { be kind to them." }\end{array}$ \\
\hline $\begin{array}{l}\text { Natural/part } \\
\text { of me }\end{array}$ & $\begin{array}{l}\text { Discussed SMEs as a } \\
\text { naturally occurring part of } \\
\text { everyday life }\end{array}$ & 4 & $9.8 \%$ & $\begin{array}{l}\text { "I feel it's part of who I } \\
\text { am." }\end{array}$ \\
\hline Pets & $\begin{array}{l}\text { Mentioned pets involved in } \\
\text { SMEs in a meaningful way }\end{array}$ & 2 & $4.9 \%$ & $\begin{array}{l}\text { "A voice came through } \\
\text { explaining that his old } \\
\text { friend (a dog he had as a } \\
\text { child) was alive and well } \\
\text { and waited for him in the } \\
\text { spirit world." }\end{array}$ \\
\hline $\begin{array}{l}\text { Feelings of } \\
\text { peace, love, } \\
\text { and bliss }\end{array}$ & $\begin{array}{l}\text { Described experiencing } \\
\text { powerful feelings of love, } \\
\text { peace, and bliss in relation } \\
\text { to an SME or discarnate }\end{array}$ & 1 & $2.4 \%$ & $\begin{array}{l}\text { "I have never had a dis- } \\
\text { tressing experience, only } \\
\text { happy ones that also flood } \\
\text { me with an exhilarating } \\
\text { happiness." }\end{array}$ \\
\hline
\end{tabular}


Table 3 Themes Related to Research Question 2: Distress or Challenge of SMEs $(\mathrm{N}=41)$

\begin{tabular}{|c|c|c|c|c|}
\hline Theme & Criterion & $n$ & $\%$ & Sample Statement \\
\hline $\begin{array}{l}\text { Reality/ } \\
\text { Sanity }\end{array}$ & $\begin{array}{l}\text { Discussed doubting, } \\
\text { questioning, or otherwise } \\
\text { pondering their own sanity } \\
\text { or picture of reality as they }\end{array}$ & 15 & $36.6 \%$ & $\begin{array}{l}\text { "How to integrate them into } \\
\text { my belief system. How to em- } \\
\text { brace those experiences." }\end{array}$ \\
\hline
\end{tabular}
perceive it.

$\begin{array}{ll}\text { Isolation/ } & \text { Described feeling isolated } \\ \text { Secrecy/ } & \text { from others, judged by } \\ \text { Judgment } & \text { those around them, or } \\ & \text { having a sense of secrecy } \\ & \text { around their SMEs }\end{array}$

Delivering the Right Message

$\begin{array}{ll}\text { No Distress } & \begin{array}{l}\text { Described SMEs as not } \\ \text { stressful at all }\end{array} \\ \text { Physical } & \begin{array}{l}\text { Described having physical } \\ \text { symptoms (e.g., somatic } \\ \text { pains, vomiting) as a part } \\ \text { of their SMEs }\end{array}\end{array}$

Discussed feeling a duty to deliver a correct message from discarnate to recipient
$12 \quad 29.3 \%$ "The only person in my family who tried to talk to me about [it] was my paternal grandmother and we only succeeded in doing that once so I grew up feeling afraid of 'being found out' or judged as 'weirdo."”
9

$22.0 \%$
"Wisdom, integrity, to channel them in the right time and place to the right people, in the right way. Thank God, when it happens spontaneously, most of it has been taken care of in that aspect already, indeed. But, sometimes I really feel that I need extra wisdom. For I so clearly feel the longing of the deceased person, and then I see the circumstances of the person(s) they want me to communicate their message(s) to. And I feel I have to be very cautious and considerate: to me this is very natural, to them, it isn't at all."

$7 \quad 17.1 \% \quad$ "None of the experiences have been distressing in the slightest."

$6 \quad 14.6 \% \quad$ "The fact that my heart was spasming and contracting... It felt that my heart was crying and it was a very uncomfortable feeling." 


\begin{tabular}{|c|c|c|c|c|}
\hline Theme & Criterion & $n$ & $\%$ & Sample Statement \\
\hline Startling & $\begin{array}{l}\text { Described SMEs as catch- } \\
\text { ing them off guard and } \\
\text { feeling quite surprising }\end{array}$ & 4 & $9.8 \%$ & $\begin{array}{l}\text { "Far from finding these } \\
\text { episodes a gift, I see them as a } \\
\text { curse. I really worry some- } \\
\text { times about what I'll see next, } \\
\text { and worry why it has to even } \\
\text { be this way." }\end{array}$ \\
\hline $\begin{array}{l}\text { Pain of the } \\
\text { Deceased }\end{array}$ & $\begin{array}{l}\text { Described feeling pain } \\
\text { that discarnates had } \\
\text { experienced in life }\end{array}$ & 2 & $4.9 \%$ & $\begin{array}{l}\text { "I remember seeing those } \\
\text { men with my uncle when I } \\
\text { was very young. I remember } \\
\text { seeing parts of the battle they } \\
\text { had been in and it frightened } \\
\text { me a great deal. It was upset- } \\
\text { ting to my uncle that I could } \\
\text { see them too." }\end{array}$ \\
\hline
\end{tabular}

Table 4 Themes Related to Research Question 3: Coping with SMEs ( $\mathrm{N}=41)$

\begin{tabular}{llccl}
\hline \multicolumn{1}{c}{ Theme } & \multicolumn{1}{c}{ Criterion } & $n$ & $\%$ & \multicolumn{1}{c}{ Sample Statements } \\
\hline Spiritual & Described using spiritual & 17 & $41.5 \%$ & "So I now pray about my knowl- \\
Practice & $\begin{array}{l}\text { meditation or prayer to } \\
\text { cope with SMEs }\end{array}$ & & & $\begin{array}{l}\text { edge and ask God to keep me hon- } \\
\text { est and sane and never mislead- }\end{array}$ \\
& & & & ing and to humbly speak of his \\
& & & kingdom and souls in a way that \\
& & & is truth and that honors him."
\end{tabular}

Trusting Self Discussed having to trust themselves and their perceptions regarding their SMEs

Establishing

Boundaries and Balance
Described setting boundaries in day-to-day life to deal with SMEs
$9 \quad 22.0 \% \quad$ "I am just left with a feeling that I should trust myself more, and my experiences, and stop worrying what others think because I have been given a gift that others have not, just as they may have [been] given gifts that I haven't."

$7 \quad 17.1 \% \quad$ "Learning how to have boundaries with the people who have crossed over. They try to get through to me at night, when I am relaxed and open for sleep, but I do readings for clients during the day so have already brought through people who have passed away and I need my rest, so I've had to learn how to 'close down' and have a really strong boundary in order to be 'off' when I am not working to bring through spirit people for clients." 


\begin{tabular}{|c|c|c|c|c|}
\hline Theme & Criterion & $n$ & $\%$ & Sample Statements \\
\hline $\begin{array}{l}\text { Helping } \\
\text { Others }\end{array}$ & $\begin{array}{l}\text { Discussed volunteering } \\
\text { time and energy to help } \\
\text { others as strategies to } \\
\text { cope with SMEs }\end{array}$ & 6 & $14.6 \%$ & $\begin{array}{l}\text { "I feel that I've been blessed with } \\
\text { this gift for a reason. Maybe it's } \\
\text { to help people lose their fear of } \\
\text { death and know that we still exist } \\
\text { outside of this physical realm." }\end{array}$ \\
\hline $\begin{array}{l}\text { Light as } \\
\text { Protective } \\
\text { Energy }\end{array}$ & $\begin{array}{l}\text { Referenced light as a pro- } \\
\text { tective, helpful, positive } \\
\text { life-force in which par- } \\
\text { ticipants could seek refuge } \\
\text { when SMEs became } \\
\text { overwhelming }\end{array}$ & 6 & $14.6 \%$ & $\begin{array}{l}\text { "And when I do open myself, I } \\
\text { feel myself back in the Light, sur- } \\
\text { rounded by this loving protective } \\
\text { energy." }\end{array}$ \\
\hline
\end{tabular}

participants whose narratives seemed to us to reflect the theme ( $n$ and \%), and a quote from one of the narratives that illustrated the theme (Example).

\section{Discussion and Implications}

Results of our qualitative analysis confirmed multiple findings from a prior study on SMEs among NDErs (Foster et al., 2015). The two NDErs, Alexandria and Beth, whom the prior researchers had interviewed, demonstrated themes related to the present study. They described their SME characteristics as sometimes comforting and reassuring-especially once they had a better understanding of their experiences. They also discussed feeling compelled to act or help and wanting to deliver the right message that discarnates were communicating to them, both themes in the present study. Additionally, one of the prior case study participants described the role of forgiveness in messages that discarnates wanted them to deliver to others.

In addition, Alexandria and Beth described feelings that appear consistent with the theme of isolation, secrecy, and judgment (Foster et al., 2015). During their interviews, they stated that they feared people's reactions to them. Alexandria reported that her distress was a result of others' potential reactions, and she felt concerned that "others may think she is crazy or hallucinating" (p. 47) if she were to tell them that she interacted with discarnates. Furthermore, Beth and Alexandria discussed ways in which they continued to process how to fit their experiences into their understanding of reality, which 
fits with the theme identified in this study of reality and sanity. Other findings from Alexandria and Beth's narratives that our results mirrored included themes of feeling pain of the deceased and the startling nature of their SMEs.

In Foster et al.'s (2015) investigation, Beth spoke at length about her efforts to establish a schedule and regimented process by which discarnates would communicate with her. The theme in the present study of establishing boundaries and balance reinforced that Beth is not alone in this process. Our results also supported Beth's assertion that she was dedicated to helping others as a result of her multiple and continuous SMEs. Finally, the theme of trusting self underscores Alexandria and Beth's experiences of having to have faith in themselves that their experiences were real and that they were not hallucinating or insane.

We also learned some new information about NDErs' experiences of SMEs not heretofore reported elsewhere in related scholarly literature. Over half of the participants stated that they had SMEs involving their family members. In a prior study (Foster et al., 2015), participants reported having SMEs with people they did not know. This result may mean that expanding the original definition of SMEs (Holden et al., 2014) to include experiences that involve unexpected visits from discarnate family members should be considered. Additionally, a minority of participants reported that discarnates delivered messages to them about their deceased pets, potentially underscoring depth of human-animal connections beyond the living realm. Other themes from this study that we have not otherwise seen in the NDE/SME literature are physical symptoms, in which SMErs experience physiological responses during their SMEs, and the light as protective energy, in which SMErs revisited during their SMEs an allknowing, all-loving Light they had encountered during their NDEs.

Yet other themes that emerged during our analysis need additional verification. Creswell (2012) indicated that themes can be represented by just one participant. To our knowledge, the theme capturing SMEs as peaceful, loving, and blissful has not been explored in the published literature. Although NDErs report this feature quite frequently when discussing their NDEs, this pattern has not been the case among the few SMErs who have been interviewed in detail (Foster et al., 2015). A similar theme in which participants in this study experienced SMEs as a natural parts of themselves has also not been mentioned in previous scholarship on the topic. Finally, the 
theme of no distress needs further clarity. SMErs Alexandria and Beth stated that their distress fluctuated over time, with each participant reporting unique experiences of distress related to SMEs (Foster et al., 2015). Similarly, although many participants in this study reported finding solace in spiritual practice to cope with their SMEs, this specific coping mechanism was not explored in Holden et al.'s (2014) quantitative study, perhaps due to the way those researchers designed their questions. It seems clear that these themes are open for further clarification. We posit that the lack of phenomenological qualitative research with SMErs could be one explanation for the paucity of these themes appearing in the nascent SME literature.

There were several limitations in this study. Most glaring is our process of gathering data. Because we gathered participant narratives via an online survey, we could not ask follow-up questions as one could during an in-person or telephone semi-structured interview. We found ourselves wondering about further details of participants' written reports as we examined our completed thematic analysis. In addition, because the original survey was conducted online, potential NDErs who are not comfortable in an online survey environment may not have responded, and these SMErs might be different in some way(s) from those more comfortable with information technology.

Given our results and limitations, we encourage future researchers to conduct in-person or, at the very least, telephone or videoconference qualitative interviews so that follow-up questions may be asked to participants. Additionally, with the number of emerging studies on SMEs among NDErs, future researchers can refine the questions that we and others have asked to conduct more focused investigations. For example, inquiring about intricacies of how, when, and under what circumstances discarnates communicate to NDErs during SMEs might be valuable. We believe that obtaining more information about contextual factors could be a valuable addition to a growing literature base.

Based on the present study as well as two previous studies of SMEs, our hope is that other NDE researchers will take these exploratory studies, tighten the methodological approaches, and continue to make a strong effort to understand SMEs as a potential aftereffect of NDEs. The current research team was certainly surprised during our early discussions when we realized the level of infancy that characterized our comprehension of SMEs. These early understandings present an open opportunity for further exploration. Fundamentally, we hope that the more investigators can discover about SMEs among NDErs, the bet- 
ter those who are involved with education of NDErs can assist them in their self-awareness, social support, insight, growth, and other aspects of the post-NDE integration process.

\section{References}

Creswell, J. W. (2012). Qualitative inquiry and research design: Choosing among five approaches (3rd ed.). Thousand Oaks, CA: Sage.

Foster, R. D., Lee, D., \& Duvall, A. G. (2015). Two cases of spontaneous mediumship experiences of near-death experiencers. Journal of Near-Death Studies, 34, 44-56. doi:10.17514/JNDS-2015-34-1-p44-56.

Greyson, B. (1983). The Near-Death Experience Scale: Construction, reliability, and validity. Journal of Nervous and Mental Disease, 171(6), 369-375.

Guggenheim, W., \& Guggenheim, J. A. (1995). Hello from heaven: A new field of research-After-death communication-confirms that life and love are eternal. New York, NY: Bantam.

Holden, J. M. (2018). After-death communication. In R. D. Foster \& J. M. Holden (Eds.), Connecting soul, spirit, mind, and body: A collection of spiritual and religious perspectives and practices in counseling (pp. 3-11). Alexandria, VA: Association for Spiritual, Ethical, and Religious Values in Counseling.

Holden, J. M., Foster, R. D., \& Kinsey, L. (2014). Spontaneous mediumship experiences: A neglected aftereffect of near-death experiences. Journal of NearDeath Studies, 33, 69-85. doi:10.17514/JNDS-2014-33-2-p69-85.

Knight, M. (2011). Ways of being: The alchemy of bereavement and communiqué (doctoral dissertation). Sydney, Australia: University of Sydney.

LaGrand, L. (1997). After death communication: Final farewells. Woodbury, MN: Llewellyn.

Noyes, R., Fenwick, P., Holden, J. M., \& Christian, R. (2009). Aftereffects of pleasurable Western adult near-death experiences. In J. M. Holden, B. Greyson, \& D. James (Eds.), The handbook of near-death experiences: Thirty years of investigation (pp. 41-62). Santa Barbara, CA: Praeger/ABC-CLIO.

Ring, K. (2008). The death and posthumous life of Tom Sawyer: A case study of apparent after-death communication. Journal of Near-Death Studies, 17, 111-133. doi:10.17514/JNDS-2008-17-2-p111-133.

Ryan, G. W., \& Bernard, H. R. (2003). Techniques to identify themes. Field Methods, 15(1), 85.

Streit-Horn, J. (2011). A systematic review of research on after-death communication $(A D C)$ (Doctoral dissertation). Retrieved from https://digital.library .unt.edu/ark:/67531/metadc84284/. 